\title{
Superior Hypophyseal Artery
}

National Cancer Institute

\section{Source}

National Cancer Institute. Superior Hypophyseal Artery. NCI Thesaurus. Code C33678.

An artery arising from the cerebral portion of the internal carotid artery that supplies the infundibulum of the pituitary, median eminence and the pars tuberalis. 